\title{
Climate, habitat associations and the potential distributions of Neotropical birds: Implications for diversification across the Andes
}

\author{
Carlos Daniel Cadena ${ }^{1, *}$, Carlos A. Pedraza ${ }^{1,2}$, Robb T. Brumfield ${ }^{3}$ \\ ${ }^{1}$ Laboratorio de Biología Evolutiva de Vertebrados, Departamento de Ciencias Biológicas, Universidad de los Andes, Bogotá, Colombia \\ ${ }^{2}$ The Nature Conservancy, Bogotá, Colombia \\ ${ }^{3}$ Museum of Natural Science and Department of Biological Sciences, Louisiana State University, Baton Rouge, LA, USA \\ * Inaugural article by corresponding member of the Colombian Academy of Exact, Physical and Natural Sciences in October 7, 2015.
}

\begin{abstract}
Contrary to the long-held view that the uplift of the Andes spurred biotic diversification by causing vicariance across multiple lineages with formerly continuous distributions, recent work suggests that dispersal across the Andes occurring after major uplift episodes was a major driver of speciation in Neotropical birds, with the ability of lineages to persist and disperse in the landscape being strong predictors of speciation. However, where and when dispersal events across the Andes occurred is unknown, and the role of climatic fluctuations and associated shifts in vegetation in promoting cross-Andes dispersal at different moments remains to be studied. We used models of species potential distributions based on contemporary and historical climatic data to examine scenarios of cross-Andes dispersal by 41 species of Neotropical lowland birds with varying habitat affinities. Our results indicate that ecological connectivity favoring cross-Andes dispersal at the present is higher in low-lying passes across the Andes of southern Ecuador and northern Peru than in passes in Colombia, and this spatial pattern appears to have been consistent at four different moments over the past 130,000 years. We also found that although some areas may be presently unsuitable for the dispersal of birds across the Andes, under past climatic conditions (i.e. during cooler and drier periods) they were substantially more likely to allow for ecological connectivity of populations across the cordillera. No consistent differences were found in ecological connectivity across the Andes in the present nor in the past for species occupying different habitat types. We suggest that valleys in the Andes are major drivers of evolutionary diversification not only by isolating populations of montane species, but also by allowing episodic dispersal of lowland species. Our models allow us to make predictions about gene flow which may be assessed in future studies examining fine-grain patterns of genetic exchange with landscape genetics tools. (C) Acad. Colomb. Cienc. Ex. Fis. Nat. 2016.
\end{abstract}

Key words: Andean uplift, climatic change, isolation by resistance, lowland forest, speciation, species distribution models.

Clima, asociaciones de hábitat y la distribución potencial de aves neotropicales: implicaciones para la diversificación a través de los Andes

\section{Resumen}

En contraste con la visión tradicional de que el levantamiento de los Andes impulsó la diversificación biótica causando vicarianza en varios grupos con distribuciones que antes eran continuas, investigaciones recientes sugieren que eventos de dispersión a través de los Andes sucedidos después de los principales episodios de levantamiento fueron catalizadores principales de la especiación en aves neotropicales, y que la habilidad de los linajes para persistir y dispersarse en el paisaje predice fuertemente los patrones de especiación. Sin embargo, se desconoce cuándo y dónde sucedieron dichos eventos de dispersión, y el papel de las fluctuaciones climáticas y el consecuente desplazamiento de la vegetación como promotores de la dispersión a través de los Andes en distintos momentos no ha sido estudiado. Empleamos modelos de la distribución potencial de especies basados en datos de clima actual e histórico para examinar escenarios de dispersión a través de los Andes en 41 especies de aves neotropicales de tierras bajas con diferentes afinidades de hábitat. Nuestros resultados indican que la conectividad ecológica que favorecería la dispersión a través de los Andes en el presente es mayor en pasos bajos de la cordillera del sur de Ecuador y el norte de Perú que en pasos bajos de Colombia, y este patrón espacial parece haberse mantenido en cuatro momentos diferentes de los últimos 130,000 años. También encontramos que aunque algunas áreas actualmente no serían propicias para la dispersión de las aves a través de los Andes, bajo condiciones climáticas del pasado (i.e. durante períodos más fríos y secos) presentaron condiciones climáticas sustancialmente más idóneas para permitir la conectividad ecológica de poblaciones a través de la cordillera. No encontramos diferencias consistentes en la conectividad ecológica presente y pasada a través de los Andes entre especies de diferentes tipos de hábitat. Sugerimos que los valles andinos impulsan la diversificación evolutiva 
no solo porque aíslan las poblaciones de especies de montaña, sino porque permiten la dispersión episódica de especies de las tierras bajas. Nuestros modelos permiten hacer predicciones sobre flujo genético que pueden ser evaluadas en estudios futuros que examinen patrones de intercambio genético a escala fina usando herramientas de genética del paisaje. (C) Acad. Colomb. Cienc. Ex. Fis. Nat. 2016.

Palabras clave: aislamiento por resistencia, bosque de tierras bajas, cambio climático, especiación, levantamiento andino, modelos de distribución de especies.

\section{Introduction}

Various historical hypotheses have been proposed to explain the origin of the astounding diversity of species in tropical South America. Many of these hypotheses are focused on processes leading to the geographic isolation of populations and their subsequent evolutionary differentiation; these processes include the uplift of the Andes, climatic fluctuations resulting in habitat fragmentation during the Quaternary, the emergence of riverine barriers, and marine incursions (Wallace, 1852; Haffer, 1967a; Haffer, 1969; Nores, 1999; Hoorn et al., 2010). The uplift of the Andes was an important driver of avian diversification because it resulted in the origin of novel environments to which species could disperse and diversify in, and because it promoted increased opportunities for allopatric differentiation in montane areas (Chapman, 1917; Hughes \& Eastwood, 2006). The Andes also influenced the diversification of organisms distributed in surrounding lowland areas, serving as an effective barrier isolating populations on either side of the cordillera (Chapman, 1917; Brumfield \& Capparella, 1996; Hoorn et al., 2010). Many lowland avian species are currently present on both sides of the Andes, suggesting that they were continously distributed prior to the Andean uplift or that dispersal across this newly formed barrier was plausible at times in the past (e.g. when vegetation belts were displaced upslope due to climatic change; Hooghiemstra, Wijninga \& Cleef, 2006).

Classic studies on the biogeography of Neotropical birds exposed somewhat distinct views on the role of the Andean upflit as a driver of diversification in lowland avifaunas and interpreted cross-Andes distributions in different ways. On one hand, although Chapman (1917; 1926) entertained the possibility of dispersal across or around the northern Andes, he believed this to be relatively rare and instead envisioned the existence of "a pre-Andean fauna, the Pacific portion of which has been cut off from that of upper Amazonia by the Andean uplift”. Under this vicariant scenario, populations were fragmented by the Andes and differentiated largely in allopatry owing to lack of movement of individuals across the cordillera (Chapman, 1917; Chapman, 1926). Alternatively, Haffer (1967a; 1974) believed the existence of a pre-Andean fauna in western South America to be

\footnotetext{
*Corresponding author:

Carlos Daniel Cadena, ccadena@uniandes.edu.co

Received: September 18, 2015

Accepted: May 19, 2016
}

unlikely because much of the landscape would have been covered by shallow seas prior to the uplift. Instead, he posited that, during humid periods, Amazonian species episodically "spilled over" into western South America across low passes in the Andes (Haffer, 1974) or dispersed around the Andes through the northern lowlands of Colombia (Haffer, 1967a; Haffer, 1967b). In sum, although both of these authors assigned a critical role to the Andes as a driver of the divergence of isolated lowland populations, they had different views about the relative importance of mechanisms initiating allopatric divergence across the cordillera.

A recent analysis of molecular phylogeographic data for multiple avian lineages from the Neotropical lowlands (Smith et al., 2014) rejected the hypothesis of a single vicariant event explaining population differentiation across the Andes and obtained results consistent with multiple events of cross-Andes dispersal at different moments, a result in line with previous studies on other groups (Brumfield \& Capparella, 1996; Dick, Roubik, Gruber \& Bermingham, 2004; Cheviron, Hackett \& Capparella, 2005; Miller et al., 2008). However, where and when dispersal events across the Andes occurred is not fully understood, and the role of climatic fluctuations and associated shifts in vegetation in promoting cross-Andes dispersal at different time periods remains to be studied. Another noteworthy finding of recent studies is that avian species with presumably contrasting dispersal abilities and habitat affinities differ significantly in their genetic structure and temporal patterns of speciation across the Andes and other features of the South American landscape (Bates, Tello \& Silva, 2003; Burney \& Brumfield, 2009; Cadena, Gutiérrez-Pinto, Dávila \& Chesser, 2011; Smith, Amei \& Klicka, 2012; Smith et al., 2014). Taken together, the above data suggest that achieving a comprehensive understanding of avian diversification in the Neotropics will require considering the interaction between species' ecologies and physical and climatic features of the landscape thought to isolate populations or to facilitate dispersal across putative barriers.

A wealth of recent studies have revealed that, owing to restrictions imposed by their fundamental ecological niches (Hutchinson, 1957), species' distributions can be accurately predicted by associating spatial occurrence data with environmental (e.g. climatic, topographic) variables to generate models of potential distributions (Guisan \& Thuiller, 2005). Moreover, because ecological niches tend to be evolutionarily conserved (Peterson, Soberón 
\& Sánchez-Cordero, 1999; Peterson, 2011), distribution models are often transferable in time, such that historical distributions can be predicted using current occurrence data (Martínez-Meyer, Peterson \& Hargrove, 2004; Bonaccorso, Koch \& Peterson, 2006; Martínez-Meyer \& Peterson, 2006; Ruegg, Hijmans \& Moritz, 2006; Nogués-Bravo, 2009). This opens the exciting possibility of generating hypotheses about species' historical distributions that can be tested rigorously using phylogeographic data (Hugall, Moritz, Moussalli \& Stanisic, 2002; Carstens \& Richards, 2007; Carnaval, Hickerson, Haddad, Rodrigues \& Moritz, 2009; Bell et al., 2010; Pulgarín-R. \& Burg, 2012). Here, we use species distribution modelling methods to examine scenarios of cross-Andes dispersal by Neotropical lowland birds. Specifically, we used models of species potential distributions based on contemporary and historical climatic data to address the following questions: (1) Given current climatic conditions, which passes in the Andes are more suitable for dispersal across the cordillera by species from lowland habitats? (2) How has habitat connectivity across passes in the Andes varied over time? (3) Do current and historical patterns of potential habitat connectivity across Andean passes differ between species with different habitat associations? Based on our answers to these questions, we describe new questions and challenges for future studies on the topic.

\section{Methods}

\section{Study system}

More than 100 bird species have disjunct distribution ranges in northern South America and lower Central America separated by discontinouous environments in the Andes (Smith et al. 2014). Although there is substantial variation in the distribution of species whose ranges span both sides of the Andes, two general patterns can be discerned (Figure 1). First, for ca. $90 \%$ of the species the distributions of populations east of the Andes occur to the southern and eastern border of the llanos, or, more rarely, extend to the Mérida Andes and other coastal ranges of Venezuela, either by penetrating the riparian forests of the llanos or the foothills forests along the eastern slope of the Cordillera Oriental. We refer to this as the "northern crossing distribution" because it suggests across-Andes dispersal occurred by moving through the lowlands north of the Andes (Haffer, 1967b), through the pass separating the Cordillera Oriental and Mérida Andes known as the Táchira Depression, or through the Andalucía Pass or the Suaza-Pescado valleys at the base of the Cordillera Oriental (Figure 2). Second, for the remainder ca. $10 \%$ of species, distributions of populations east of the Andes do not include northern Amazonia. We refer to this as the "southern crossing distribution" because it has been used (Chapman, 1926) to propose hypotheses of across-Andes dispersal through passes in southern Ecuador (Loja Valley) and northern Peru (Porculla Pass; Figure 2).
Species with cross-Andes distributions occur both in closed humid forests and in drier, more open environments. Our analyses focused on 41 lowland avian species with crossAndean distributions in northern South America and with different habitat associations (Table 1). Based on habitat preferences described in databases (Stotz, Fitzpatrick, Parker \& Moskovits, 1996), our experience, and that of field ornithologists consulted for this study (J. E. Avendaño, J. Pérez-Emán), we assigned each of the 41 species to one of three habitat categories: humid forest, both humid and dry forest, and dry forest and open areas (Table 1).

\section{Species distribution modelling}

Species presence records were obtained from the Louisiana State University Museum of Natural Science (http:// appl003.lsu.edu/natsci/lmns.nsf/index), BIOMAP project (http:// www.biomap.net/), speciesLink (http://www.splink. org.br/), Sistema de Información sobre Biodiversidad de Colombia (SiB; http://www.siac.net.co/), GBIF (http:// www.gbif.org/), and the Colección Ornitológica Phelps (http://fundacionwhphelps.org/). Because some locations in databases lacked spatial coordinates or were georeferenced inaccurately, we used gazetteers (Paynter, 1997; Sua, Mateus \& Vargas, 2004) and various sources of digital cartography to georeference data based on descriptions of localities. All individual records of each species were mapped and suspicious records (i.e. those without locality information or with considerable deviations from the known geographic or elevational ranges of species) were eliminated. This resulted in a total of 17,404 presence records, which we used to model species potential distributions (mean 415.9 SD 232.6 records per species; Figure 3).

We associated distribution records with 19 climate variables (30'"resolution clipped to continental areas ranging from $26^{\circ} 12^{\prime} \mathrm{N}$ to $35^{\circ} 20 \mathrm{~S}$ and from $34^{\circ} 42^{\prime} \mathrm{W}$ to $109^{\circ} 45^{\prime} \mathrm{W}$; Figure 3 ), which describe annual trends and extreme or limiting environmental factors in current climate (Hijmans, Cameron, Parra, Jones \& Jarvis, 2005). The maximum entropy method implemented in MAXENT (Phillips, Anderson \& Schapire, 2006) was used to predict the potential distributions of species at present using species locations and presentday climate layers. We set MAXENT parameters as autofeatures mode, with 10,000 background samples representing the climatic conditions of the analyzed area. We used $75 \%$ of the data for model training using present climatic conditions and $25 \%$ for validation purposes. Outputs were defined as a logistic format interpretable as the probability of presence conditioned on environmental variables (Phillips et al., 2006). Model performance was determined by using the AUC, i.e. the area under receiver-operator curves (Fielding \& Bell, 1997). Using a large number of climatic variables to generate species distribution models may result in model overfitting; accordingly, researchers often minimize the number of variables included in models by excluding those strongly 


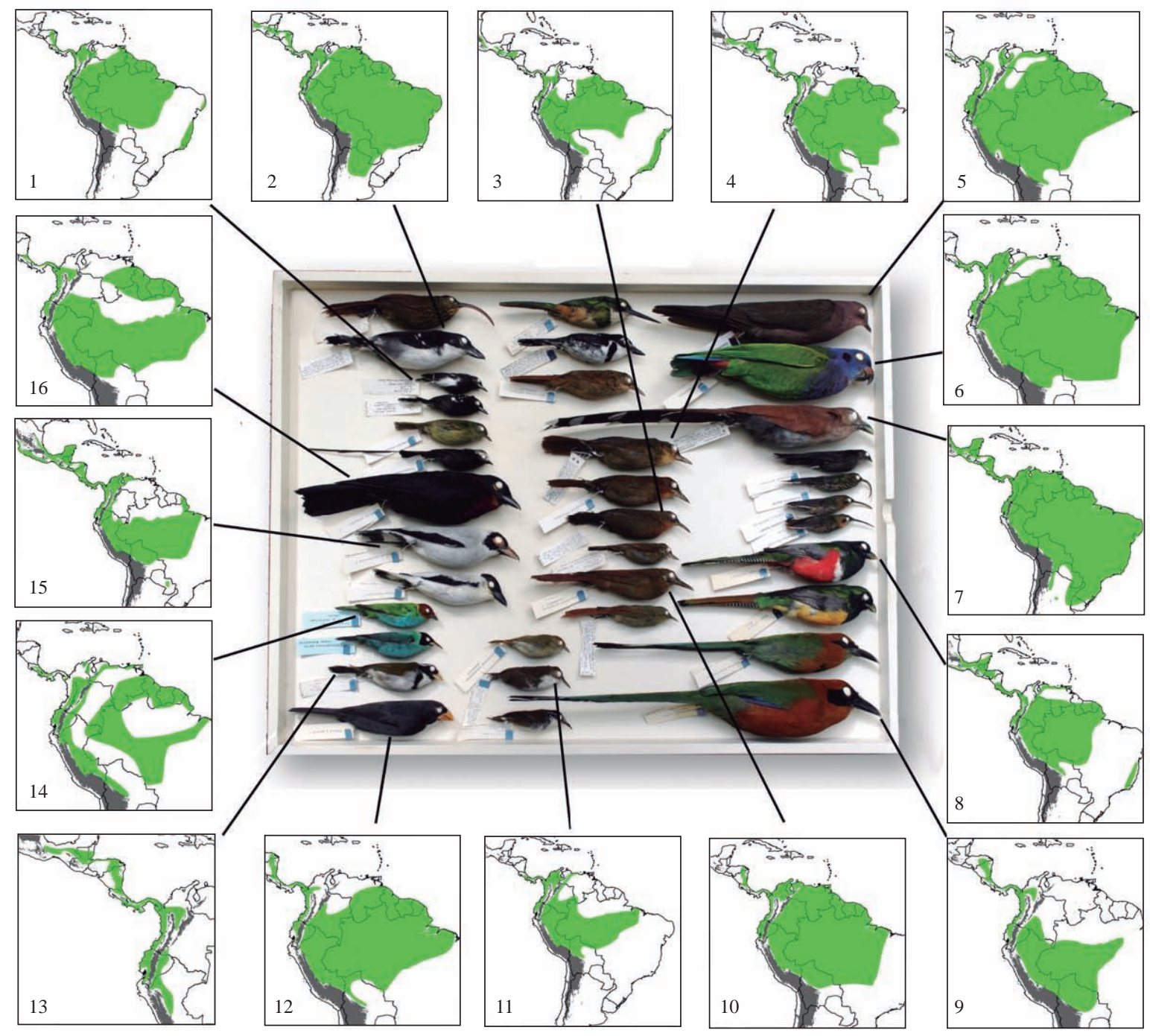

Figure 1. A sampling of specimens of lowland Neotropical birds with cross-Andes distribution ranges selected to show the diversity of taxa with populations on both sides of the Andes. For a subset of the species, range maps (taken from NatureServe (Ridgely et al., 2005)) are shown to illustrate a variety of distribution patterns. Most range maps shown are examples of the "northern crossing" distribution pattern; maps 9 and 13 are examples of the "southern crossing” distribution pattern. 1. Myrmotherula axillaris (Thamnophilidae), 2. Taraba major (Thamnophilidae), 3. Sclerurus mexicanus (Furnariidae), 4. Automolus ochrolaemus (Furnariidae), 5. Patagioenas speciosa (Columbidae), 6. Pionus menstruus (Psittacidae), 7. Piaya cayana (Cuculidae), 8. Trogon collaris (Trogonidae), 9. Baryphthengus martii (Momotidae), 10. Dendrocincla fuliginosa (Furnariidae), 11. Microcerculus marginatus (Troglodytidae), 12. Saltator grossus (Incertae Sedis), 13. Arremon aurantiirostris (Emberizidae), 14. Tangara gyrola (Thraupidae), 15. Tityra semifasciata (Tityridae), 16. Querula purpurata (Cotingidae). Photograph and figure design by C. Burney and L. Céspedes.

correlated to others or by reducing the dimensionality of data using principal components analysis. However, we chose to include all 19 WorldClim variables in our models because correlations among variables differed between species from dry and humid forests, and we were interested in predicting potential distributions using the same climatic variables across all species. In addition, model overfitting may be less of a problem for situations with a large number of localities per species like in our study, and we note that MAXENT incorporates a penalization for terms included in the model using a regularization multiplier that guards agains problems related to overparametrization (Phillips et al., 2006).
Climate-based models accurately predicted species distributions in the present (mean AUC 0.9437, SD 0.0187). This allowed us to project models onto layers depicting reconstructions of past climate to generate hypotheses of historical distributions; this approach assumes niche conservatism, that climate constrains species' distributions and that species distributions at present are at equilibrium with current climate (Peterson et al., 1999; Peterson, 2003; Carnaval et al., 2009; Tingley, Monahan, Beissinger \& Moritz, 2009). Specifically, models were projected to the past to infer potential distributions in the Mid Holocene -6 thousand years before present (kyr BP)—, the Last Glacial 


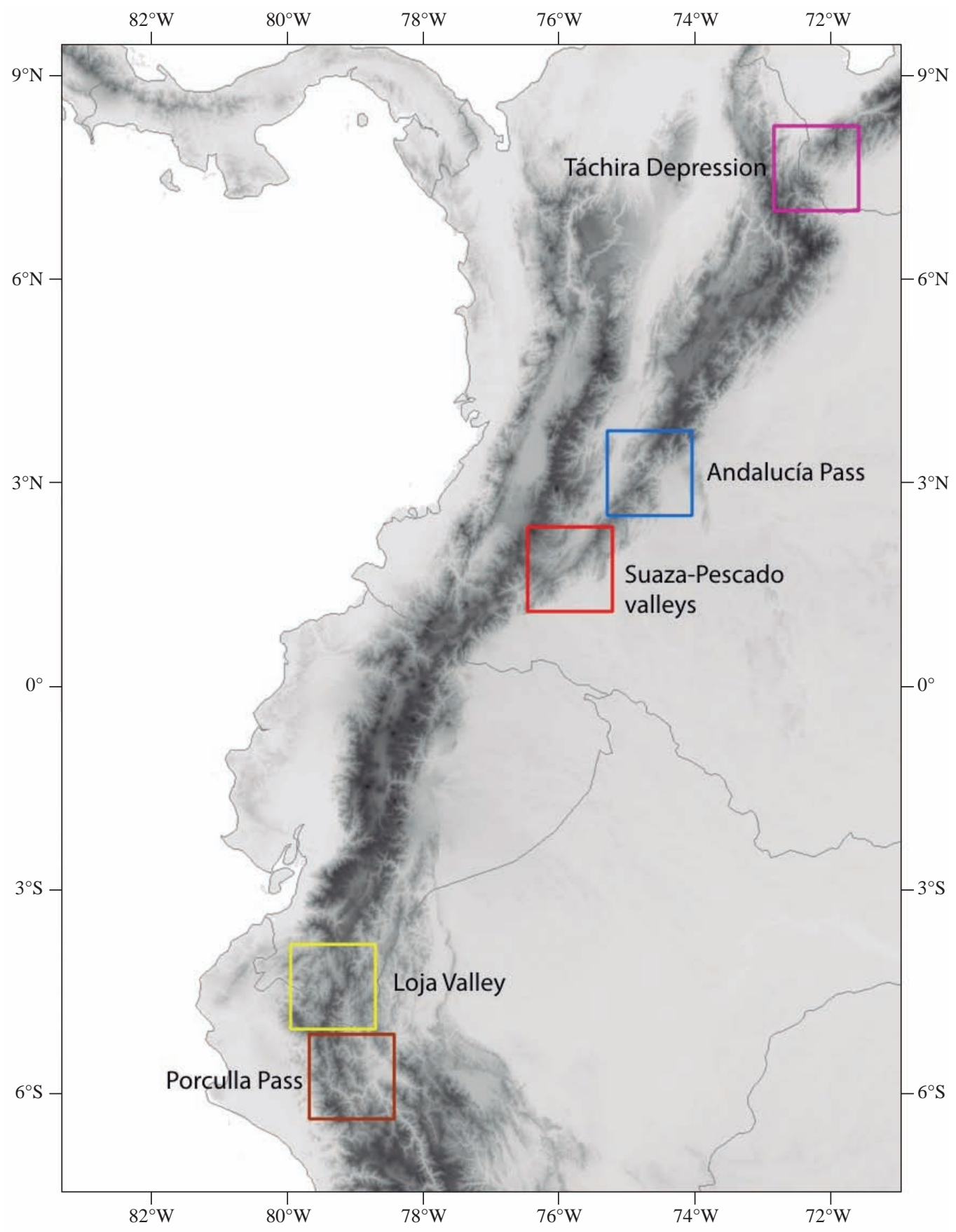

Figure 2. Topographic map of northern South America showing the location of low-lying passes in the Andes across which avian species may have dispersed. We refer to the pass in southern Ecuador as the Loja Valley following Chapman (1926), but note that because the Loja Valley does not face the Amazon basin, the area might be best referred to as Loja-Zamora valleys (Krabbe, 2008). The literature has focused on the Táchira and Andalucía passes in Colombia, but preliminary analyses for this study revealed the existence of another area through which species may cross south of Andalucía; we refer to this pass as that of the Suaza-Pescado valleys based on rivers flowing through the area.

Maximum —LGM, 21 kyr BP- (Braconnot et al., 2007), and the last interglaciation period -130-116 kyr BP(Kukla et al., 2002; Otto-Bliesner et al., 2006). Climatic data for these historical periods were also obtained from WorldClim (http://www.worldclim.org/paleo-climate).

\section{Estimating connectivity across passes}

We measured ecological connectivity across passes in the Andes for lowland species of birds with ranges on both sides of the cordillera using an approach grounded in electrical circuit theory (McRae, 2006). This approach allows one 
Table 1. Bird species included in our analyses of ecological connectivity of potential distributions across the Andes in the present and at three moments in the past. For each species, habitat affinites are indicated.

\begin{tabular}{|c|c|c|c|}
\hline & Humid forest & Dry forest & Open areas \\
\hline \multicolumn{4}{|l|}{ Trochilidae } \\
\hline Glaucis hirsuta & $\mathrm{X}$ & & \\
\hline \multicolumn{4}{|l|}{ Thamnophilidae } \\
\hline Cymbilaimus lineatus & $\mathrm{X}$ & & \\
\hline Taraba major & $\mathrm{X}$ & & \\
\hline Thamnophilus doliatus & & $\mathrm{X}$ & \\
\hline Dysithamnus mentalis & $\mathrm{X}$ & & \\
\hline Myrmotherula ignota/obscura & $\mathrm{X}$ & & \\
\hline Formicivora grisea & $\mathrm{X}$ & $\mathrm{X}$ & \\
\hline \multicolumn{4}{|l|}{ Furnariidae } \\
\hline Sclerurus mexicanus & $\mathrm{X}$ & & \\
\hline Sittasomus griseicapillus & $\mathrm{X}$ & & \\
\hline Glyphorynchus spirurus & $\mathrm{X}$ & & \\
\hline Clibanornis rubiginosus & $\mathrm{X}$ & & \\
\hline Automolus ochrolaemus & $\mathrm{X}$ & & \\
\hline Synallaxis albescens & & $\mathrm{X}$ & $\mathrm{X}$ \\
\hline \multicolumn{4}{|l|}{ Tyrannidae } \\
\hline Elaenia flavogaster & & & $\mathrm{X}$ \\
\hline Mionectes oleagineus & $\mathrm{X}$ & & \\
\hline Myiophobus fasciatus & & & $\mathrm{X}$ \\
\hline Terenotriccus erythrurus & $\mathrm{X}$ & & \\
\hline Colonia colonus & $\mathrm{X}$ & & $\mathrm{X}$ \\
\hline \multicolumn{4}{|l|}{ Cotingidae } \\
\hline Querula purpurata & $\mathrm{X}$ & & \\
\hline \multicolumn{4}{|l|}{ Pipridae } \\
\hline Manacus manacus & $\mathrm{X}$ & $\mathrm{X}$ & \\
\hline $\begin{array}{l}\text { Ceratopipra erythrocephala } \\
\text { Tityridae }\end{array}$ & $\mathrm{X}$ & & \\
\hline Tityra inquisitor & $\mathrm{X}$ & & \\
\hline Tityra semifasciata & $\mathrm{X}$ & & \\
\hline Schiffornis turdina (sensu lato) & $\mathrm{X}$ & & \\
\hline \multicolumn{4}{|l|}{ Troglodytidae } \\
\hline Microcerculus marginatus & $\mathrm{X}$ & & \\
\hline Cantorchilus leucotis & $\mathrm{X}$ & & \\
\hline Henicorhina leucosticta & $\mathrm{X}$ & & \\
\hline \multicolumn{4}{|l|}{ Poliotpilidae } \\
\hline Microbates cinereiventris & $\mathrm{X}$ & & \\
\hline \multicolumn{4}{|l|}{ Thraupidae } \\
\hline Eucometis penicillata & $\mathrm{X}$ & $\mathrm{X}$ & \\
\hline Tachyphonus luctuosus & $\mathrm{X}$ & & \\
\hline Thraupis episcopus & & $\mathrm{X}$ & $\mathrm{X}$ \\
\hline Tangara gyrola & $\mathrm{X}$ & & \\
\hline Tersina viridis & $\mathrm{X}$ & $\mathrm{X}$ & \\
\hline Chlorophanes spiza & $\mathrm{X}$ & & \\
\hline Cyanerpes caeruleus & $\mathrm{X}$ & & \\
\hline Sporophila nigricollis & & & $\mathrm{X}$ \\
\hline \multicolumn{4}{|l|}{ Emberizidae } \\
\hline Arremon aurantiirostris & $\mathrm{X}$ & & \\
\hline \multicolumn{4}{|l|}{ Cardinalidae } \\
\hline Habia rubica & $\mathrm{X}$ & & \\
\hline Cyanocompsa cyanoides & $\mathrm{X}$ & & \\
\hline \multicolumn{4}{|l|}{ Incertae Sedis } \\
\hline Saltator maximus & $\mathrm{X}$ & & \\
\hline \multicolumn{4}{|l|}{ Icteridae } \\
\hline Psarocolius angustifrons & $\mathrm{X}$ & & \\
\hline
\end{tabular}

to calculate resistance distances over a landscape; such distances measure the opposition of the environments in a given grid cell to movement of organisms. The inverse of resistance (conductance) can be interpreted to represent the likelihood of a dispersing individual choosing to move through a given grid cell relative to others available and in population-genetic applications is a proxy for migrants exchanged between populations (McRae, Dickson, Keitt \& Shah, 2008). We calculated resistance/conductance distances using CIRCUITSCAPE, an algorithm that jointly considers random-walk theory and the effect on connectivity of multiple routes linking two localities (McRae et al., 2008). Resistance distances estimated using this approach have been shown to outperform traditional population genetic models (isolation by distance, least-cost path models) in predicting population structure (McRae \& Beier, 2007), suggesting they are an appropriate measure of ecological connectivity in space.

To measure ecological connectivity across five main Andean passes hypothesized to have allowed for dispersal of avian species across the cordillera in Colombia, Ecuador and northern Peru (Chapman, 1917; Chapman, 1926; Haffer, 1967a; Haffer, 1967b), we delimited a 50x50 km quadrat around each pass (Figure 2). We then used surfaces with relative probabilities of presence generated for each of our study species (i.e. the MAXENT output of potential distribution models) to calculate cross-Andean connectivity at each pass for each species and at each time period as the conductance (i.e. the inverse of resistance) estimated using circuit-theory models of all alternative pathways crossing the Andes in the defined quadrat (McRae et al., 2008). To compare connectivity among passes and among time periods, we used mean conductance values across the 50 $1 \mathrm{x} 1 \mathrm{~km}$ pixels contained within each quadrat.

\section{Results}

We illustrate our approach with an analysis of the potential distribution of White-bearded Manakin (Manacus manacus) at present and at the LGM focusing on the Andalucía Pass sector of the Cordillera Oriental of Colombia (Figure 4). The potential distribution range of this species appears to have been smaller and more discontinuous during the LGM than at present; a dimensionless proximity metric calculated by estimating the distance of every patch of suitable habitat to its nearest suitable neighboring patch (Gustafson \& Parker, 1992) averaged ( \pm SD) $1552 \pm 202$ for the LGM and 7427 \pm 1347 for the present. Not only do potential ranges differ across time periods in size and continuity, but also in the suitability of the Andalucía Pass for the presence of the species. Although this pass is climatically unsuitable for $M$. manacus at present, the model suggests it was potentially suitable at the LGM, when there was much greater potential for connectivity between populations from the eastern slope of the Andes and the upper Magdalena Valley (Figure 4). 


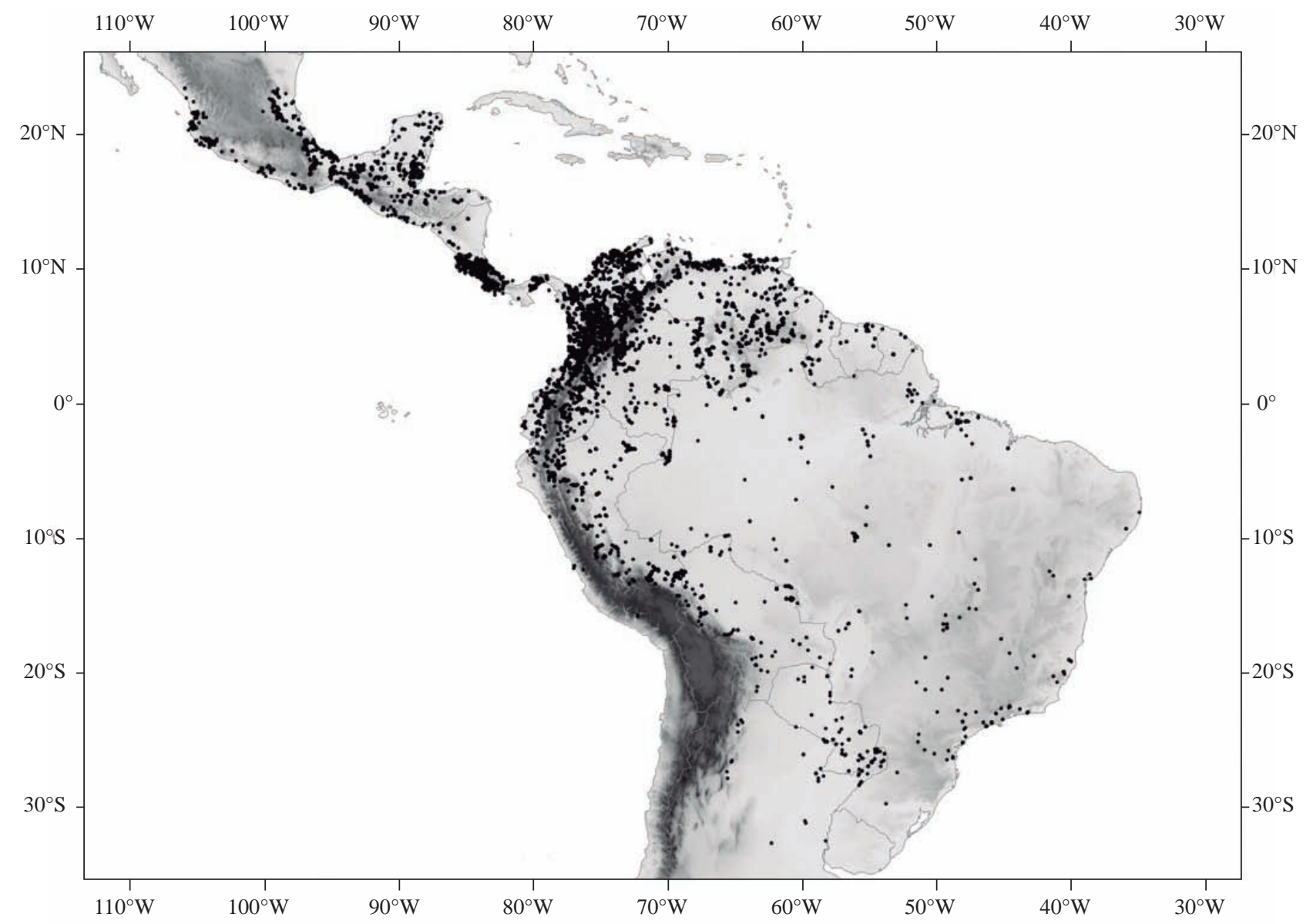

Figure 3. Study area and location of 17,404 presence records used to model the potential distributions of 41 avian species with crossAndean distributions in the Neotropical lowlands.

Based on analyses of the present-day potential distributions of our 41 study species, conductance index values are highest across the Porculla Pass, suggesting this area is most suitable for dispersal of species across the Andes given current climatic conditions; connectivity of potential species distributions across the Andes is intermediate in the Loja, Táchira, and Andalucía passes, and lowest in the SuazaPescado pass (Figure 5). Present-day patterns in climatic connectivity across the Andes are similar to those estimated for $6 \mathrm{kyr}$ BP. Conductance index values were considerably different at earlier periods (21 and $130 \mathrm{kyr}$ BP; see below), but the overall pattern persisted over time: connectivity was consistently highest across the Porculla pass and lowest across the Suaza-Pescado pass across all time periods.

Our models indicate that relative to the present, connectivity of potential species distributions across the Andes was generally greater during the LGM (21 kyr BP) and 130 kyr BP than 6 kyr BP and at present (Figure 5). For the two southernmost passes (Loja and Porculla), connectivity was estimated to be greatest during the LGM, but for the northern passes (Táchira, Andalucía, and Suaza-Pescado) connectivity was similar during the LGM and $130 \mathrm{kyr}$ BP.
We found no consistent effects of the habitat affinities of species on patterns of climatic connectivity across Andean passes at different moments in time (Figure 5). Species in all three habitat categories showed the general pattern of increased potential connectivity 21 and $130 \mathrm{kyr}$ BP relative to $6 \mathrm{kyr} \mathrm{BP}$ and the present, with some minor exceptions. First, connectivity across the Táchira and Andalucía passes for species occupying both humid and dry forests during the LGM tended to be lower than that estimated for species from only humid or only dry/open areas, and did not differ from estimates for 6 kyr BP and the present. Second, connectivity across the Suaza-Pescado, Loja, and Porculla passes at the LGM (and at $130 \mathrm{kyr}$ BP por the latter two passes) tended to be greater for species from humid forests relative to those in other habitat categories.

\section{Discussion}

The uplift of the Andes undoubtedly had far-reaching effects on the Neotropical landscape and on the organisms occupying it. For avian species from lowland environments, the Andean uplift had various consequences for mechanisms affecting speciation, which include the physical isolation of populations 

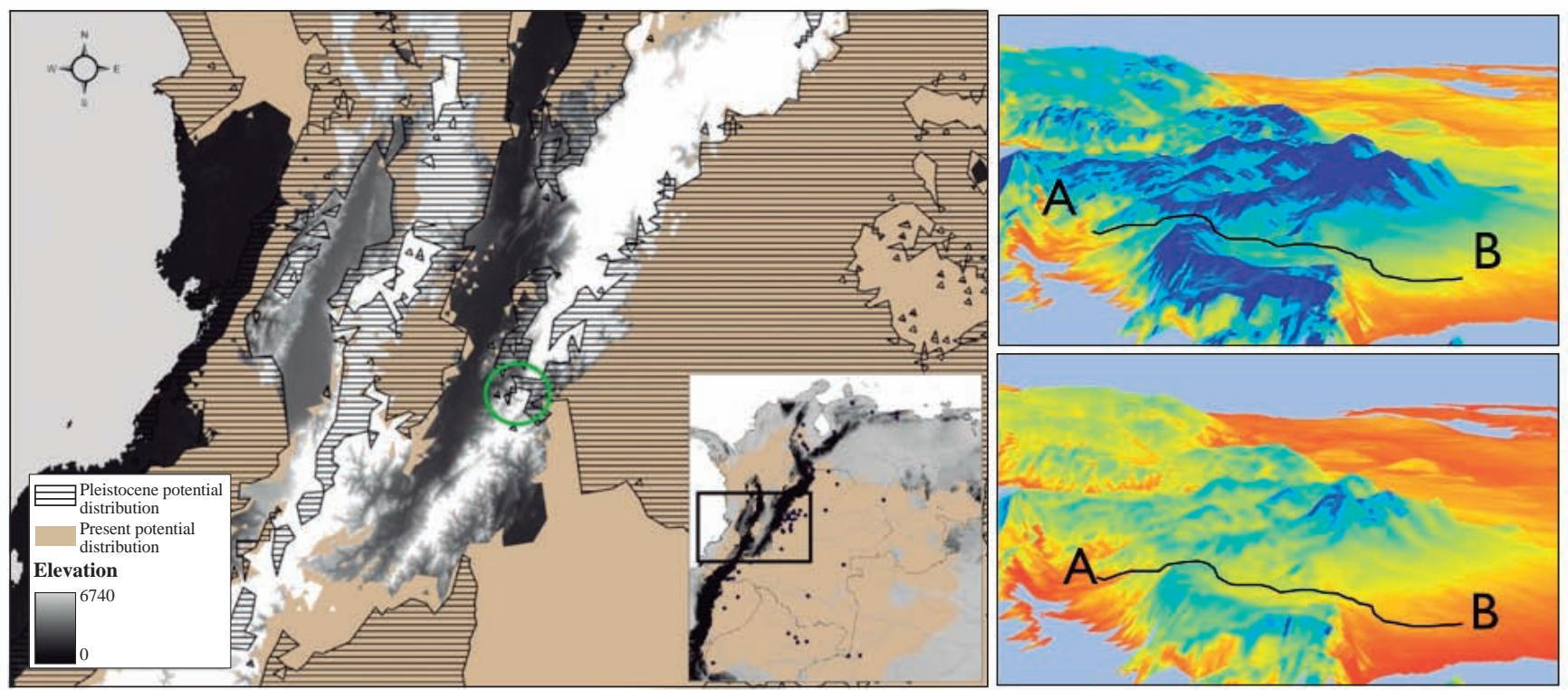

Figure 4. Left: Comparison of the predicted potential distributions of Manacus manacus for the present (brown) and the Pleistocene LGM (21 kyr BP; horizontal hatching) in Colombia suggests that the species’ potential range extended more to the west in the past, crossing over the highest point in the Cordillera Oriental at the Andalucía Pass (encircled in green) to the Magdalena Valley slope. The inset shows the point localities used to build the model and the predicted potential distribution at present at a broader scale, which agrees well with the known distribution range of this taxon. Right: detailed view of the Andalucía Pass showing the relative probability of occurrence of M. manacus (more suitable sites are shown in orange/yellow, unsuitable sites in cyan/blue) in the region at present (top) and during the LGM (bottom). Note the much greater potential for connectivity across the Andes between points A and B (the line indicates a hypothetical crossing route across the cordillera) in the historical potential distribution.

on either side of the cordillera, the formation of the Amazon River system in its current configuration, and changes in precipitation patterns leading to the ecological isolation of large blocks of humid forest by arid environments (Haffer, 1967a; Haffer, 1967b; Hoorn et al., 2010). Accordingly, a large body of work on Neotropical avian biogeography has focused on describing patterns of genetic differentiation and area relationships seeking to test predictions of hypotheses linking Andean orogeny with evolutionary diversification (Brumfield \& Capparella, 1996; Antonelli, Nylander, Persson \& Sanmartín, 2009; Antonelli et al., 2010; Ribas, Aleixo, Nogueira, Miyaki \& Cracraft, 2012). Consensus appears to be emerging that the hypothesis that Andean uplift resulted in pervasive cross-species vicariance and long-term, persistent isolation of avian populations separated by the cordillera is unlikely to be true: species with cross-Andes distributions are now known to have dispersed episodically across the cordillera (Miller et al., 2008), and cross-species analyses reveal patterns of genetic variation inconsistent with simultaneous vicariance (Smith et al., 2014). Thus, the data are more consistent with the hypothesis that cross-Andes distributions involve dispersal events than with the hypothesis of a pre-Andean fauna fragmented by the uplift (Chapman, 1917; Chapman, 1926; Haffer, 1967a; Haffer, 1967b).

Given incongruence across species in the timing of divergence across physical barriers and given effects of dispersal abilities on patterns of population structure and speciation across the Neotropical landscape, Smith et al. (2014) recently proposed a model of avian diversification in the region which posits that speciation is often initiated via episodic dispersal across barriers. Under this model, allopatric speciation is not directly linked to changes such as the uplift of the Andes, but rather is initiated by dispersal events, with the main drivers of diversification being the abilities of lineages to disperse and persist in a landscape previously structured by large-scale tectonic/ geologic processes (Smith et al., 2014). Under this model, understanding to what extent cross-Andes dispersal was plausible for species with different ecologies at different times and at different places is of central importance. The work presented in this study based on geographical projections of models of species potential distributions onto reconstructions of historical climates is a first approximation to addressing these issues.

Previous assessments of the suitability of passes in the Andes for dispersal of birds across the cordillera were based on subjective verbal descriptions of habitat features based on field observations. For example, the Andalucía Pass was considered to be an unlikely route for the crossing of species from the eastern lowlands west to the upper Magdalena Valley of Colombia due to it exhibiting "temperate" ecological conditions unsuitable for lowland forms (Miller, 1952). Based on this ecological argument, Haffer (1967a) posited that "a direct crossing of the mountains in this area 

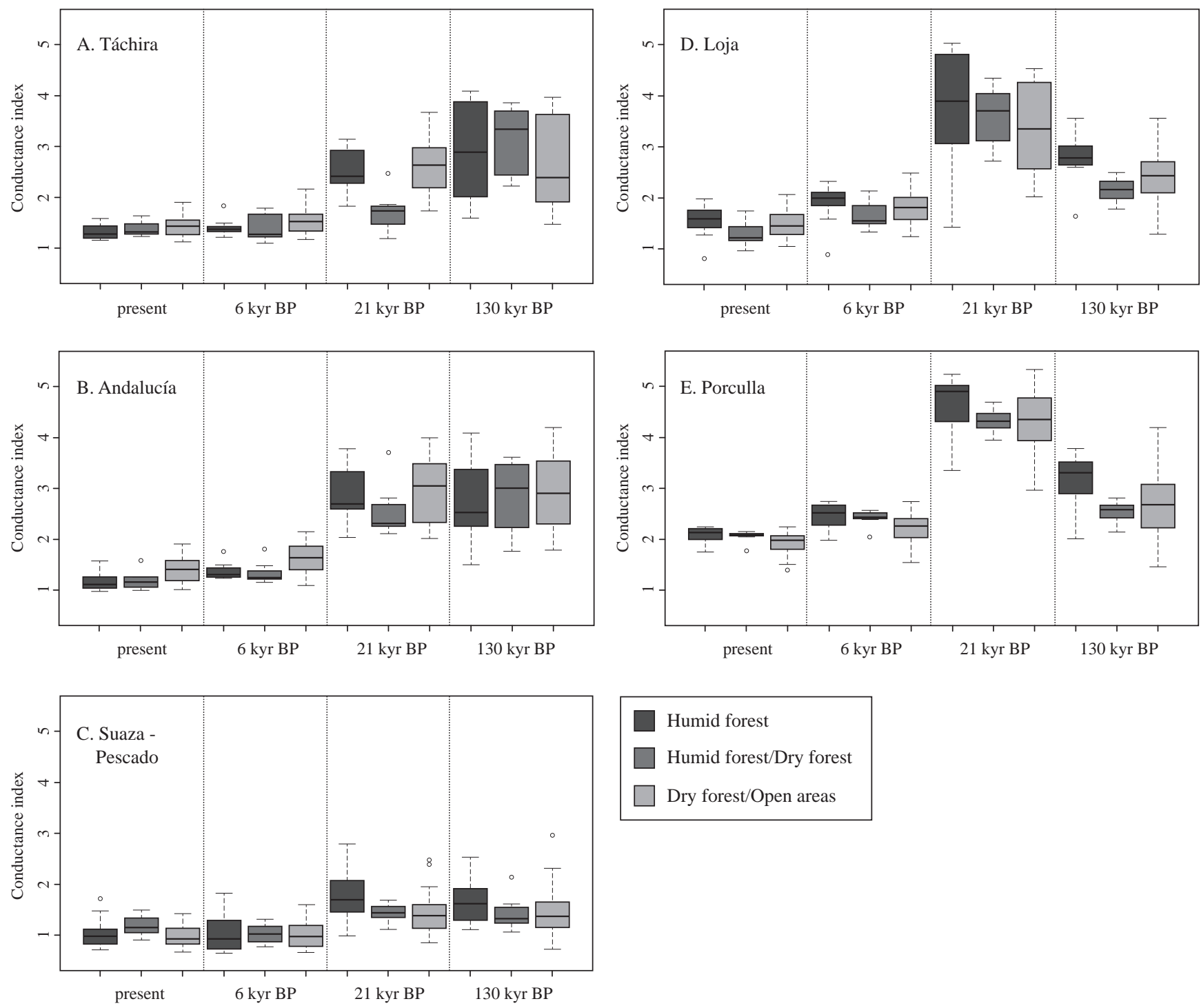

Figure 5. Connectivity across five Andean passes at present and at three moments in the past estimated based on species distribution models constructed for avian species in three habitat categories using climatic data. Connectivity is expressed using a conductance index estimated using an isolation-by-resistance model, with larger values indicating greater connectivity of climatically suitable environments (i.e. lower resistance to dispersal).

appears impossible” and hypothesized that “Amazonian species advanced exclusively around the northern tip of the Colombian Andes". However, recent spatial analyses of climatic data indicate that thermal regimes in areas such as the Andalucía Pass differ only slightly from those of lowland areas (Zuloaga \& Kerr, 2016), implying that dispersal across these passes would not be entirely unexpected, particularly at times when vegetation currently restricted to the lowlands occupied higher elevations. Indeed, our analyses suggest that although the Andalucía Pass is indeed unsuitable at present for the dispersal of lowland species of birds across the Andes, climatic conditions in the area in the past (i.e., 21 and $130 \mathrm{kyr}$ BP) were considerably more suitable for dispersal. More generally, our work shows that although current climates across most of the passes hypothesized to allow for cross-Andes connectivity may not enable dispersal of individuals or for extensions of population ranges at present, conditions during cooler periods in the past were more conducive to establishing connectivity and may have accounted for episodic dispersal events (e.g., Miller et al., 2008). Of course, this idea is not new, as there is extensive palynological evidence of upslope displacement of ecosystems presently restricted to the lowlands in association with global cooling (Hooghiemstra et al., 2006; Flantua et al., 2014); however, ours is the first analysis using climatic data associated with species potential distributions to quantitatively document patterns of this sort. 
Much of the literature on the effects of climatic change on avian speciation (e.g., the Pleistocene refugia model) has focused on the influence of declines in precipitation associated with global cooling driving habitat fragmentation and thus promoting allopatric speciation via vicariance (Haffer, 1969; Haffer \& Prance, 2001). Our analyses are consistent with the additional hypothesis that climatic change may also be a major driver of speciation by linking rather than fragmenting habitats. By temporarily facilitating dispersal across otherwise unsurmountable barriers such as the Andean passes studied here, climatic change likely contributes to the initiation of differentiation in allopatry via dispersal, a central component of the diversification model of Smith et al. (2014). Climatic change allowing for extensions of the geographical ranges of populations is not only relevant for Neotropical diversification in relation to dispersal across the Andes, but it likely applies to other geographic settings. For example, colonization and diversification events across the Isthmus of Panama were likely influenced importantly by changes in connectivity driven by climate (Smith et al., 2012; Bacon et al., 2015; Bacon et al., 2016).

Our analyses indicate that ecological opportunities for dispersal across the Andes have been greater in the Porculla Pass of northern Peru and the Loja Valley of southern Ecuador relative to the Táchira Depression separating the Colombian and Venezuelan Andes or the Andalucía Pass in the Cordillera Oriental of Colombia. This may reflect contrasting climatic regimes between the areas where southern and northern passes are located related to the dynamics of main atmospheric circulation features (i.e. the South American monsoon and the Inter Tropical Convergence Zone); in addition, areas in the south likely maintained humid climatic conditions during the LGM, a time when areas in the northern Andes of Colombia became considerably drier (Marchant et al., 2004; Marchant et al., 2009; Cheng et al., 2013). Overall, our results thus suggest that the area where southern passes are located has likely played an important role in the evolution of Neotropical birds by serving as a corridor creating connections between separate geographic realms, especially during cooler periods. In turn, the same general area has spurred population divergence acting as a critical barrier limiting the dispersal of species from upper elevations (Winger \& Bates, 2015). This highlights the important role of valleys in the Andes -and other montane regions (Robin, Vishnudas, Gupta \& Ramakrishnan, 2015) - as drivers of evolutionary diversification both by triggering dispersal and by causing or maintaining population isolation.

To conclude, we note that arguably the greatest value of using distribution models to infer patterns in the historical ranges of species is that such models may allow the generation of hypotheses that one may subsequently test using phylogeographic data (Hugall et al., 2002; Carstens \& Richards, 2007; Carnaval et al., 2009; Bell et al., 2010;
Pulgarín-R. \& Burg, 2012). For example, if the patterns recovered by our models are correct and apply not only to the periods we studied but more generally to other cool/ dry vs. warm/wet periods of the past, then one would predict (1) higher levels of gene flow between lowland populations across southern Ecuador and northern Peru than in Colombia, (2) no differences in gene flow across Andean passes in species from dry and open habitats, or (3) cross-Andes dispersal events in lowland species clustering at moments in the past when models suggested higher ecological connectivity across passes. Following the era of documenting general patterns of population structure across the Andes (Smith et al., 2014 and references therein), a fruitful area of inquiry for future work in the field would be to examine fine-grain patterns of genetic exchange integrating tools from landscape genetics with species distribution modeling.

\section{Acknowledgements}

We are grateful to Catalina Gonzalez for helpful comments on drafts of this manuscript and for her assistance with interpretation of climatic data. The manuscript was also improved thanks to comments from Ana Carolina Carnaval and three anonymous reviewers. Miguel Lentino provided locality data from the Colección Ornitológica Phelps, and Curt Burney and Laura Céspedes assisted with figure preparation. Our collaboration was greatly facilitated by financial support from the United States National Science Foundation (award DEB-0841729).

\section{Conflict of interests}

The authors declare no conflicts of interest of any kind.

\section{Bibliography}

Antonelli, A., Nylander, J.A.A., Persson, C., Sanmartín, I. 2009. Tracing the impact of the Andean uplift on Neotropical plant evolution. Proceedings of the National Academy of Sciences of the USA 106: 9749-9754.

Antonelli, A., Quijada-Mascareñas, A., Crawford, A.J., Bates, J.M., Velazco, P.M., Wüster, W. 2010. Molecular studies and phylogeography of Amazonian tetrapods and their relation to geological and climatic models. In: Hoorn, C. and Wesselingh, F.P., eds. Amazonia, landscape and species evolution: a look into the past: Wiley-Blackwell. 386-404.

Bacon, C.D., Molnar, P., Antonelli, A., Crawford, A.J., Montes, C., Vallejo-Pareja, M.C. 2016. Quaternary glaciation and the Great American Biotic Interchange. Geology 44: 375-378.

Bacon, C.D., Silvestro, D., Jaramillo, C., Smith, B.T., Chakrabarty, P., Antonelli, A. 2015. Biological evidence supports an early and complex emergence of the Isthmus of Panama. Proceedings of the National Academy of Sciences of the USA 112: 6110-6115.

Bates, J.M., Tello, J.G., Silva, J.M.C. 2003. Initial assessment of genetic diversity in ten bird species of South American cerrado. Studies on Neotropical Fauna and Environment 38: 87-94. 
Bell, R.C., Parra, J.L., Tonione, M., Hoskin, C.J., Mackenzie, J.B., Williams, S.E., Moritz, C. 2010. Patterns of persistence and isolation indicate resilience to climate change in montane rainforest lizards. Molecular Ecology 19: 2531-2544.

Bonaccorso, E., Koch, I., Peterson, A.T. 2006. Pleistocene fragmentation of Amazon species' ranges. Diversity and Distributions 12: 157-164.

Braconnot, P., Otto-Bliesner, B., Harrison, S., Joussame, S., Peterchmitt, J.-Y., Abe-Ouchi, A., Crucifix, M., Driesschaert, E., Fichefet, T., Hewitt, C.D., Kageyama, M., Kitoh, A., Lainé, A., Loutre, M.-F., Marti, O., Merkel, U., Ramstein, G., Valdes, P., Weber, S.L., Yu, Y., Zhao, Y. 2007. Results of PMIP2 coupled simulations of the Mid-Holocene and Last Glacial Maximum. 1. Experiments and large-scale features. Climate of the Past 3: 261-277.

Brumfield, R.T., Capparella, A.P. 1996. Historical diversification of birds in northwestern South America: a molecular perspective on the role of vicariant events. Evolution 50: 1607-1624.

Burney, C.W., Brumfield, R.T. 2009. Ecology predicts levels of genetic differentiation in Neotropical birds. American Naturalist 174: 358-368.

Cadena, C.D., Gutiérrez-Pinto, N., Dávila, N., Chesser, R.T. 2011. No population genetic structure in a widespread aquatic songbird from the Neotropics. Molecular Phylogenetics and Evolution 58: 540-545.

Carnaval, A.C., Hickerson, M.J., Haddad, C.F.B., Rodrigues, M.T., Moritz, C. 2009. Stability predicts genetic diversity in the Brazilian Atlantic Forest hotspot. Science 323: 785-789.

Carstens, B.C., Richards, C.L. 2007. Integrating coalescent and ecological niche modeling in comparative phylogeography. Evolution 61: 1439-1454.

Chapman, F.M. 1917. The distribution of bird life in Colombia. Bulletin of the American Museum of Natural History 36: 1-169.

Chapman, F.M. 1926. The distribution of bird-life in Ecuador. Bulletin of the American Museum of Natural History 55: 1-784.

Cheng, H., Sinha, A., Cruz, F.W., Wang, X., Edwards, R.L., d'Horta, F.M., Ribas, C.C., Vuille, M., Stott, L.D., Auler, A.S. 2013. Climate change patterns in Amazonia and biodiversity. Nature Communications 1: 1411-1416.

Cheviron, Z.A., Hackett, S.J., Capparella, A.P. 2005. Complex evolutionary history of a Neotropical lowland forest bird (Lepidothrix coronata) and its implications for historical hypotheses of the origin of Neotropical avian diversity. Molecular Phylogenetics and Evolution 36: 338-357.

Dick, C.W., Roubik, D.W., Gruber, K.F., Bermingham, E. 2004. Long-distance gene flow and cross-Andean dispersal of lowland rainforest bees (Apidae: Euglossini) revealed by comparative mitochondrial DNA phylogeography. Molecular Ecology 13: 3775-3785.

Fielding, A.H., Bell, J.F. 1997. A review of methods for the assessment of prediction errors in conservation presence/ absence models. Environmental Conservation 24: 38-49.
Flantua, S.G.A., Hooghiemstra, H., Van Boxel, J.H., Cabrera, M., González-Carranza, Z., González-Arango, C. 2014. Connectivity dynamics since the Last Glacial Maximum in the northern Andes; a pollen-driven framework to assess potential migration. In: Stevens, W.D., Montiel, O.M. and P., R., eds. Paleobotany and Biogeography: A Festschrift for Alan Graham in His 80th Year. St. Louis, MO, USA: Missouri Botanical Garden Press. 98-123.

Guisan, A., Thuiller, W. 2005. Predicting species distribution: offering more than simple habitat models. Ecology Letters 8: 993-1009.

Gustafson, E.J., Parker, G.R. 1992. Relationships between landcover proportion and indices of landscape spatial pattern. Landscape Ecology 7: 101-110.

Haffer, J. 1967a. Speciation in Colombian forest birds west of the Andes. American Museum Novitates 2294: 1-57.

Haffer, J. 1967b. Zoogeographical notes on the "nonforest" lowland bird faunas of northwestern South America. Hornero 10: 315-333.

Haffer, J. 1969. Speciation in Amazonian forest birds. Science 165: 131-137.

Haffer, J. 1974. Avian speciation in tropical South America with a systematic survey of the toucans (Ramphastidae) and the jacamars (Galbulidae). Nuttall Ornithological Club: Cambridge, Massachusetts.

Haffer, J., Prance, G.T. 2001. Climatic forcing of evolution in Amazonia during the Cenozoic: on the refuge theory of biotic differentiation. Amazoniana 16: 579-607.

Hijmans, R.J., Cameron, S.E., Parra, J.L., Jones, P.G., Jarvis, A. 2005. Very high resolution interpolated climate surfaces for global land areas. International Journal of Climatology 25: $1965-1978$.

Hooghiemstra, H., Wijninga, V.M., Cleef, A.M. 2006. The paleobotanical record of Colombia: implications for biogeography and biodiversity. Annals of the Missouri Botanical Garden 93: 297-324.

Hoorn, C., Wesselingh, F.P., ter Steege, H., Bermudez, M.A., Mora, A., Sevink, J., Sanmartín, I., Sanchez-Meseguer, A., Anderson, C.L., Figueiredo, J.P., Jaramillo, C., Riff, D., Negri, F.R., Hooghiemstra, H., Lundberg, J., Stadler, T., Särkinen, T., Antonelli, A. 2010. Amazonia through time: Andean uplift, climate change, landscape evolution, and biodiversity. Science 330: 927-931.

Hugall, A., Moritz, C., Moussalli, A., Stanisic, J. 2002. Reconciling paleodistribution models and comparative phylogeography in the wet tropics rainforest land snail Gnarosophia bellendenkerensis (Brazier 1875). Proceedings of the National Academy of Sciences of the USA 99: 6112-6117.

Hughes, C., Eastwood, R. 2006. Island radiation on a continental scale: exceptional rates of plant diversification after uplift of the Andes. Proceedings of the National Academy of Sciences of the USA 103: 10334-10339.

Hutchinson, G.E. 1957. Concluding remarks. Cold Spring Harbor Symposia on Quantitative Biology 22: 415-442. 
Krabbe, N. 2008. Arid valleys as dispersal barriers to high-Andean forest birds in Ecuador Cotinga 29: 28-30.

Kukla, G.J., Bender, M.L., de Beaulieu, J.-L., Bond, G., Broecker, W.S., Cleveringa, P., Gavin, J.E., Herbert, T.D., Imbrie, J., Jouzel, J., Keigwin, L.D., Knudsen, K.L., McManus, J.F., Merkt, J., Muhs, D.R., Müller, H., Poore, R.Z., Porter, S.C., Seret, G., Shackleton, N.J., Turner, C., Tzedakis, P.C., Winograd, I.J. 2002. Last Interglacial climates. Quaternary Research 58: 2-13.

Marchant, R., Boom, A., Behling, H., Hooghiemstra, H., Melief, B., Van Geel, B., Van der Hammen, T., Wille, M. 2004. Colombian vegetation at the Last Glacial Maximum: a comparison of model- and pollen-based biome reconstructions. Journal of Quaternary Science 19: 721-732.

Marchant, R., Cleef, A., Harrison, S.P., Hooghiemstra, H., Markgraf, V., van Boxel, J., Ager, T., Almeida, L., Anderson, R., Baied, C., Behling, H., Berrio, J.C., Burbridge, R., Björck, S., Byrne, R., Bush, M., Duivenvoorden, J., Flenley, J., De Oliveira, P., van Geel, B., Graf, K., Gosling, W.D., Harbele, S., van der Hammen, T., Hansen, B., Horn, S., Kuhry, P., Ledru, M.-P., Mayle, F., Leyden, B., Lozano-García, S., Melief, A.M., Moreno, P., Moar, N.T., Prieto, A., van Reenen, G., Salgado-Labouriau, Schäbitz, F., Schreve-Brinkman, E.J., Wille, M. 2009. Pollen-based biome reconstructions for Latin America at 0, 6000 and 18000 radiocarbon years ago. Climate of the Past 5: 725-767.

Martínez-Meyer, E., Peterson, A.T. 2006. Conservatism of ecological niche characteristics in North American plant species over the Pleistocene-to-Recent transition. Journal of Biogeography 33: 1779-1789.

Martínez-Meyer, E., Peterson, A.T., Hargrove, W.W. 2004. Ecological niches as stable distributional constraints on mammal species, with implications for Pleistocene extinctions and climate change projections for biodiversity. Global Ecology and Biogeography 13: 305-314.

McRae, B.H. 2006. Isolation by resistance. Evolution 60: 15511561.

McRae, B.H., Beier, P. 2007. Circuit theory predicts gene flow in plant and animal populations. Proceedings of the National Academy of Sciences of the USA 104: 19885-19890.

McRae, B.H., Dickson, B.G., Keitt, T.H., Shah, V.B. 2008. Using circuit theory to model connectivity in ecology, evolution, and conservation. Ecology 89: 2712-2724.

Miller, A.H. 1952. Supplementary data on the tropical avifauna of the arid upper Magdalena Valley of Colombia. Auk 69: 450-457.

Miller, M.J., Bermingham, E., Klicka, J., Escalante, P., Amaral, F.S.R., Weir, J.T., Winker, K. 2008. Out of Amazonia again and again: episodic crossing of the Andes promotes diversification in a lowland forest flycatcher. Proceedings of the Royal Society of London B 275: 1133-1142.

Nogués-Bravo, D. 2009. Predicting the past distribution of species climatic niches. Global Ecology and Biogeography 18: 521-531.
Nores, M. 1999. An alternative hypothesis for the origin of Amazonian bird diversity. Journal of Biogeography 26: 475-485.

Otto-Bliesner, B.L., Marshall, S.J., Overpeck, J.T., Miller, G.H., Hu, A., members, C.L.I.P. 2006. Simulating Arctic climate warmth and icefield retreat in the last interglaciation. Science 311: 1751-1753.

Paynter, R.A., Jr. 1997. Ornithological gazetteer of Colombia, second edition. Museum of Comparative Zoology, Harvard University: Cambridge, Massachusetts.

Peterson, A.T. 2003. Predicting the geography of species' invasions via ecological niche modeling. Quarterly Review of Biology 78: 419-433.

Peterson, A.T. 2011. Ecological niche conservatism: a timestructured review of evidence. Journal of Biogeography 38: $817-827$.

Peterson, A.T., Soberón, J., Sánchez-Cordero, V. 1999. Conservatism of ecological niches in evolutionary time. Science 285: 1265-1267.

Phillips, S.J., Anderson, R.P., Schapire, R.E. 2006. Maximum entropy modeling of species geographic distributions. Ecological Modelling 190: 231-259.

Pulgarín-R., P.C., Burg, T.M. 2012. Genetic signals of demographic expansion in Downy Woodpecker (Picoides pubescens) after the last North American glacial maximum. PloS One 7: e40412.

Ribas, C.C., Aleixo, A., Nogueira, A.C.R., Miyaki, C.Y., Cracraft, J. 2012. A palaeobiogeographic model for biotic diversification within Amazonia over the past three million years. Proceedings of the Royal Society of London B 279: 681-689.

Ridgely, R.S., Allnutt, T.F., Brooks, T., McNicol, D.K., Mehlman, D.W., Young, B.E., Zook, J.R. 2005. Digital distribution maps of the birds of the Western Hemisphere, version 2.1. NatureServe: Arlington, Virginia, USA.

Robin, V.V., Vishnudas, C.K., Gupta, P., Ramakrishnan, U. 2015. Deep and wide valleys drive nested phylogeographic patterns across a montane bird community. Proceedings of the Royal Society of London B 282: 20150861.

Ruegg, K.C., Hijmans, R.J., Moritz, C. 2006. Climate change and the origin of migratory pathways in the Swainson's thrush, Catharus ustulatus. Journal of Biogeography 33: 1172-1182.

Smith, B.T., Amei, A., Klicka, J. 2012. Evaluating the role of contracting and expanding rainforest in initiating cycles of speciation across the Isthmus of Panama. Proceedings of the Royal Society of London B. 279: 3520-3526

Smith, B.T., McCormack, J.E., Cuervo, A.M., Hickerson, M.J., Aleixo, A., Cadena, C.D., Pérez-Emán, J., Burney, C.W., Xie, X., Harvey, M.G., Faircloth, B.C., Glenn, T.C., Derryberry, E.P., Prejean, J., Fields, S., Brumfield, R.T. 2014. The drivers of tropical speciation. Nature. 515: 406-409. 
Stotz, D.F., Fitzpatrick, J.W., Parker, T.A.I., Moskovits, D.K. 1996. Neotropical birds: ecology and conservation. The University of Chicago Press: Chicago.

Sua, S., Mateus, R.D., Vargas, J.C. 2004. Georreferenciación de registros biológicos y gacetero digital de localidades. Instituto de Investigación de Recursos Biológicos Alexander von Humboldt: Bogotá, Colombia.

Tingley, M.W., Monahan, W.B., Beissinger, S.R., Moritz, C. 2009. Birds track their Grinnellian niche through a century of climate change. Proceedings of the National Academy of Sciences of the USA 106 (Suppl. 2): 19637-19643.
Wallace, A.R. 1852. On the monkeys of the Amazon. Proceedings of the Zoological Society of London 20: 107-110.

Winger, B.M., Bates, J.M. 2015. The tempo of trait divergence in geographic isolation: Avian speciation across the Marañon Valley of Peru. Evolution 69: 772-787.

Zuloaga, J., Kerr, J.T. 2016. Over the top: do thermal barriers along elevation gradients limit biotic similarity? Ecography in press. 